\title{
İç Kontrol Sisteminde Satın Alma ve Ödeme Faaliyetlerine Yönelik Riskler ve Alınabilecek Önlemler \\ Risks and Measures of Purchasing and Payment Activities in Internal Control System
}

\author{
Hakkı FINDIK \\ Kırklareli Üniversitesi \\ İktisadi ve İdari Bilimler Fakültesi \\ İşletme Bölümü / Muhasebe ve Finansman A.B.D. \\ Kırklareli, Türkiye \\ hakkifindik@klu.edu.tr
}

\begin{abstract}
Özet
Küresel düzeyde yaşanan muhasebe ve denetim skandalları işletmelerin finansal tablolar üzerindeki doğruluk ve dürüstlük iddiasında önemli şüpheler oluşturmuştur. Kurumsal yönetim bağlamında işletme yöneticilerinin iç kontrol sistemlerini tasarlamaları ve etkin bir şekilde işleyişini sağlamaları hem faaliyetlerin etkinliği ve verimliliğini artırmakta hem de finansal raporların güvenirlik düzeyini yükseltmektedir. İç kontrol sistemi, döngü yaklaşımı çerçevesinde ele alındığında satın alma ve ödeme faaliyet döngüsünde hata ve hileler çokça görülebilmektedir. Bu çalışmada satın alma ve ödeme döngüsündeki riskler, riske karşılık alınabilecek önlemler ile hata ve hileye ilişkin politika ve prosedürlerin belirlenmesi ele alınmıştır.
\end{abstract}

Anahtar Kelimeler: İç kontrol sistemi, satın alma ve ödeme faaliyet döngüsü, risk, hata ve hile.

\section{Abstract}

The accounting and auditing scandals seen in global scale have created significant scepticisms about accuracy and honesty claim on the financial reports of business managements. The fact that business administrators design internal control systems with respect to institutional management and make it to operate efficiently both increases the efficiency and productivity of activities and raises the reliability level of financial reports. When internal control system is handled within the frame of cycle approach, faults and frauds are mostly seen in the purchase and payment cycle. In this study, the determination of the risks in purchase and payment cycle, of the precautions to be taken for the risk and of the politics and procedures regarding fault and fraud have been tackled.

Keywords: Internal control system, purchase and payment cycle, risk, fault and fraud. 


\section{Giriş}

Finansal karar alan tarafların anlaşılabilir, karşılaştırılabilir, ihtiyaca uygun, doğru ve dürüst bilgi ihtiyacı, işletme faaliyetlerinin kurumsal yönetim anlayışıyla organize edilmesiyle mümkündür. İşletme faaliyetleri organize edilirken bir işlemin başlangıcından sonuna kadar devam ettiği silsile etrafında değerlendirilmesi "faaliyet döngüsü" yaklaşımını ifade etmektedir.

İşletmede mal veya hizmetlere ihtiyaç duyulması ile başlayan ve satın alınan mal veya hizmetlere ait ödemenin yapılması ile son bulan satın alma süreci, yönetilmesi oldukça zor bir süreçtir. Bu kapsamda kullanılan belgelerin fazlalığı, farklı çalışanların olması, farklı bölümlerin döngüde görev alması gibi hususlar bu döngüyü hata ve hilelere açık hale getirmektedir. İşletmeyi hata ve hileden koruyacak başarılı bir döngü oluşturmanın yolu etkin bir iç kontrol sisteminin tasarlanması ve uygulanması ile mümkündür.

Bu çalışmada, satın alma ve ödeme faaliyet döngüsü üzerinde işletmelerin maruz kaldıkları riskler, risklerin analizi, risklerin önlenmesi için yapılması gerekli politika, prosedür ve eylemler ile hata ve hileler incelenmiştir. İlk olarak, iç kontrol sistemi ve bağımsız denetimde iç kontrol sisteminin önemi açıklanmıştır. Daha sonra satın alma ve ödeme faaliyet döngüsü tanıtılmış, hata ve hile riski odaklı olarak döngüdeki olası riskler belirlenmiş ve bu risklere verilebilecek karşılıklar incelenmiştir.

\section{2. İç Kontrol Sistemine Genel Bakış}

İç kontrol, bir süreçtir. Finansal ve faaliyet odaklı işlemlerin kurumsal yönetim anlayışı kapsamında yönetilebilmesi için gerekli politika ve prosedürlerin belirlenmesi iç kontrol sistemini oluşturan ögelerdendir. İşletmelerin sahipleri, ortakları, yöneticileri ve çalışanları gibi işletme içi taraflar bu süreçte aktif görev ve sorumluluklara sahiptir. Aynı zamanda işletme dışında yer alan satıcılar, müşteriler, kamu kurumları ve hizmet sağlayıcılar gibi taraflar da iç kontrol sisteminin işleyişinde taraf konumundadırlar.

\section{1. İç Kontrol Sistemi ve Kapsamı}

İç kontrol, belirlenen amaç ve hedeflere ulaşmak amacıyla işletme yönetimi tarafından kabul edilen politikalar, prosedürler, usul ve yöntemlerin tamamıdır (Aksoy, 2007, s. 216). İyi bir iç kontrol sisteminin kurulması ile güvenilir bilgiye erişimin sağlanması, işletme varlıkları ve kayıtlarının korunması, verimliliğin artırılması ve işletme politikalarına/prosedürlerine bağlılığın artırılması sağlanmaktadır (Güredin, 2007, s. 318).

İşletmelerdeki muhasebe skandallarını engelleyebilmenin en önemli adımlarından birisi etkin bir iç kontrol yapısına sahip olabilmektir. Etkin işleyişi bulunmayan zayıf bir iç kontrol sistemine sahip işletmelerde finansal kayıplar, suiistimaller, hata ve hilelerin olma ihtimali oldukça yüksektir. Hatalı ve hileli finansal raporlamayı önleyecek kritik öneme sahip eşik, kurumsal yönetim kapsamında iç kontrol sisteminin etkin hale getirilmesidir (Atmaca, 2012, s. 202). İç kontrol sistemi, işletme içi ve diş1 etkenler tarafından belirlenir. İç etmenler arasında yönetimin felsefesi, organizasyon yapısı, personel, iç denetim, bütçeleme gibi unsurlar yer alırken, dış etmenler arasında işletme yönetimi kontrolü dışında yer alan ekonomik koşullar gibi faktörler sayılabilir (Güredin, 2007, s. 324). İç kontrol sisteminde hata ve hileleri engelleyebilmek amaciyla etkili bir muhasebe sistemi kurularak muhasebe bilgilerinin güvenirliliği artırılmalıdır. Kontrol 
prosedürleri ise, işletmenin amaçlarına ulaşabilmek için yürütülen faaliyetlerde yönetim tarafından oluşturulan uyulması gereken politika ve prosedürlerdir (Bozkurt, 2006, ss. 123-126).

1992 yilinda kurulan COSO (Committee of Sponsoring Organizations of the Treadway Commission) iç kontrol sistemi ile ilgili işletmelere ve varlık değerleme şirketlerine iç kontrol sistemlerini tasarlama ve uygulama çalışmalarında yardım etmektedir. Yöneticiler, kurul üyeleri, düzenleyici kurumlar, standart düzenleyiciler, profesyonel organizasyonlar ve diğer ilgililer COSO'dan sıkça yararlanmaktadır. COSO, iç kontrol sistemini kontrol çevresi, risk değerleme, kontrol eylemleri, bilgi ve iletişim ile izleme olmak üzere beş bileşen olarak incelemiştir (Hightower, 2009, s. 7). 2004 yılında COSO'da yapılan güncelleme ile kurumsal risk yönetimi öne çıkarılmış olup, bu beş unsura "hedeflerin belirlenmesi", "olay tanımlanması" ve "riske cevap verme" olmak üzere üç unsur daha ilave edilmiştir (Schaeffer, 2006, s. 26).

\section{2. İç Kontrol Sistemine Yönelik Yapılmış Bilimsel Çalışmalar Literatürü}

Satın alma ve ödeme faaliyetlerine yönelik olarak; Kaiser vd. (2001), sağlık hizmetlerinde çevresel satın alma ve yaşam döngüsünü ve Murray (2009), İngiltere kamu sektöründe gerçekleştirilen satın alma ve teslim alma arasındaki farklılıkları incelemiştir. Sevim ve Gül (2012), elektronik işletmelerde satın alma işlemleri ve iç kontrol ilişkisini konu edinen çalışmasında, satın alma iş ve işlem akışını elektronik ortamda yürütülmesi için gerekli kontrol prosedürlerinin üzerinde durmuştur. Ceran ve Bezirci (2011), iç kontrol sisteminin stok hesapları açısından ele almış; uygunluk ve maddi doğruluk testleri kapsamında stokların satın alınması, korunması ve denetimini incelemiştir. Mengi (2013a), satıcı veya çalışan-satıcı işbirliği ile gerçekleştirilen satıcı hileleri, bu hilelere karşı alınabilecek önlemler ve gerçekleştirilmiş hilelerin ortaya çıkarılması için gerekli çalışmaları ele almıştır.

İç kontrol sistemine yönelik olarak yapılan çalışmalar ise Tablo 1'de sunulmuştur:

Tablo 1: İç Kontrol Sistemine Yönelik Yapılan Bilimsel Çalışmalar Literatürü

\begin{tabular}{|l|l|}
\hline Yazar ve Yayın Yılı & Konusu \\
\hline $\begin{array}{l}\text { Schonberger R. J. ve } \\
\text { Gilbert J. P. (1983) }\end{array}$ & $\begin{array}{l}\text { Tam zamanında üretim sisteminde satın alma faaliyetleri } \\
\text { ve ABD firmaları için karşılaşılan zorluklar }\end{array}$ \\
\hline Ellram ve Siferd (1993) & Satın alma işlemlerinde toplam maliyete yönelik esaslar \\
\hline Demirbaş (2005) & $\begin{array}{l}\text { İç kontrol sistemine ilişkin düzenlemelerin getirdiği } \\
\text { değişiklikler }\end{array}$ \\
\hline Erol (2008) & Hata ve hileye karşı denetimden beklentiler \\
\hline $\begin{array}{l}\text { Rae ve Subramaniam } \\
(2008)\end{array}$ & $\begin{array}{l}\text { Çalışan hileleri ve örgütsel adalet yönetimine ilişkin iç } \\
\text { kontrol prosedürleri }\end{array}$ \\
\hline Demirbaş (2008) & Public Company Accounting Oversight Board'a göre iç \\
\hline
\end{tabular}




\begin{tabular}{|c|c|}
\hline & kontrol faaliyetleri \\
\hline Gönen (2009) & $\begin{array}{l}\text { İç kontrol sistemi bileşenlerinden kontrol ortamına } \\
\text { yönelik bir saha çalışması }\end{array}$ \\
\hline Güner (2009) & $\begin{array}{l}\text { Kamu idarelerinin etkin yönetiminde iç kontrol } \\
\text { uygulamaları }\end{array}$ \\
\hline Tuan (2009) & $\begin{array}{l}\text { Bağımsız denetim faaliyetinin gerçekleştirilmesinde iç } \\
\text { kontrol sisteminin değerlendirilmesi }\end{array}$ \\
\hline Dabbağoğlu (2009) & İç kontrol sistemi ve önemi \\
\hline Uysal (2010) & İnsan kaynakları yönetimi açısından iç kontrol sistemi \\
\hline Güner (2010) & Kontrol ortamı ve kamu idaresinde saha araştırması \\
\hline Uyar (2010) & $\begin{array}{l}\text { Uluslararası muhasebe standartlarının uygulanmasında iç } \\
\text { kontrol sisteminin etkisi ve önemi }\end{array}$ \\
\hline Göçen (2010) & $\begin{array}{l}\text { Kurumsal yönetim ve bağımsız denetim açısından iç } \\
\text { kontrol sistemi }\end{array}$ \\
\hline Akyel (2010) & $\begin{array}{l}\text { İç kontrol sistemi, Türkiye'de uygulanması ve kamu } \\
\text { yönetimi açısından durum değerlendirmesi }\end{array}$ \\
\hline Usul vd. (2011) & $\begin{array}{l}\text { Kurumsal yönetim etkinliği açısından iç kontrol sistemi } \\
\text { ve belediyelere yönelik saha araştırması }\end{array}$ \\
\hline Ömürbek ve Altay (2011) & Turizm işletmeleri açısından iç kontrol sistemi \\
\hline Özten ve Karğın (2012) & $\begin{array}{l}\text { Bankacılık işlemlerinde kredi kontrolünün sağlanmasında } \\
\text { iç kontrol faaliyetleri }\end{array}$ \\
\hline Hermanson vd. (2012) & $\begin{array}{l}\text { COSO modeli kapsamında iç kontrol sistemi unsurlarına } \\
\text { yönelik uygulama }\end{array}$ \\
\hline Türedi (2012) & İç kontrol sistemi ve toplam kalite yönetimi ilişkisi \\
\hline Morrill ve Morrill (2012) & $\begin{array}{l}\text { Genel Kabul Görmüş Denetim Standartları ve } \\
\text { Uluslararası Denetim Standartlarına risk odaklı yaklaşım }\end{array}$ \\
\hline Atmaca (2012) & Muhasebe skandallarının önlenmesinde iç kontrol sistemi \\
\hline Akbulut (2012) & İç kontrol sisteminin etkinliği ve saha araştırması \\
\hline Okutmuş ve Uyar (2014) & Hile ve bir vaka analizi \\
\hline Ceyhan ve Apan (2014) & $\begin{array}{l}\text { COSO iç kontrol bileşenlerinin yapısal eşitlik modeli } \\
\text { yardımıyla incelenmesi }\end{array}$ \\
\hline $\begin{array}{l}\text { Schroeder ve Shepardson } \\
(2016)\end{array}$ & $\begin{array}{l}\text { İç kontrol kalitesini } \text { etkileyen } \text { işletme yönetimi } \\
\text { değerlendirmeleri }\end{array}$ \\
\hline
\end{tabular}

İç kontrol sistemine yönelik yapılan saha araştırmalarının bazılarının sonuçları şu şekildedir: 
Usul vd. (2011), iç kontrol sisteminin kurumsal yönetim etkinliğine yönelik belediyelere yönelik yaptığı saha araştırmasında, belediyelerde teorik anlamda şeffaflık, eşitlik ve sorumluluk gibi ilkelerin bulunmadığı sonucuna ulaşmıştır.

Ömürbek ve Altay (2011), iç kontrol sistemini turizm işletmeleri üzerinde incelemiş ve otellerde yaptığı araştırmada en çok yiyecek içecek bölümünde iç kontrol sisteminin etkin olmadığını belirlemiştir.

Hermanson vd. (2012), 500 iç denetçi ile yaptıkları saha araştırmasında; iç kontrol unsurları kamu firmalarında, diğer firmalara göre daha etkin çalıştığını tespit etmiştir. Bankalar ve finansal hizmetler sunan firmalarda izleme bileşeni, sağlık ve diğer hizmet sağlayıcı işletmelere göre daha güçlü çalışmaktadır.

Akbulut (2012), ayçiçek yağı sektöründe iç kontrol sisteminin etkinliğini incelediği çalışmasında, anket yapılan 34 firmanın iç kontrol sistemlerine önem vermediği sonucuna varmıştır.

Okutmuş ve Uyar (2014), bir vaka analizi yardımıyla konaklama işletmelerinde yiyecek-içecek bölümünde yapılan hilelerin tespitini konu edindiği çalışmasında, analitik inceleme tekniği ile hilenin tespiti yapılmıştır. Hilenin parasal etkisi hesaplanarak, yönetsel raporu da oluşturulmuş ve iç kontrol prosedürlerine örnekler verilmiştir.

Ceyhan ve Apan (2014), COSO iç kontrol modelini hastane işletmesi üzerinde yapısal eşitlik modeli ve faktör analizi uygulayarak incelemiştir. Araştırmada kontrol çevresi, risk değerleme, kontrol faaliyetleri, izleme, iletişim ve organizasyon yapısı arasında pozitif yönlü bir ilişski belirlenmiştir.

\subsection{Faaliyet Döngüleri Kapsamında İç Kontrol Sistemi}

İç kontrol sistemi içerisinde işletme yönetimi, değişen koşullara göre karşılaşılması muhtemel riskleri belirler, değerlendirir ve önlem alma suretiyle risklere karşılık verir. İç kontrol sisteminin kurulmasında işletme faaliyetlerinin döngü yaklaşımı ile organize edilmesi işletmelerin sıkça başvurduğu bir yoldur. İşletme faaliyetleri; "satın alma ve ödeme", "satış ve tahsilat", "stok ve üretim", “insan kaynakları ve bordro", "maddi duran varlık" ve "nakit ve benzerleri” döngüleri gibi kendi içerisinde bütünlük arz eden farklı işlemlerin bir arada değerlendirilmesi ile organize edilmektedir.

Çalışmanın buradan sonraki kısmında satın alma ve ödeme faaliyet döngüsünde risklerin belirlenmesi, riske karşılık verilmesi ve hata/hile gibi hususlar üzerinde durulacaktır. Satın alma ve ödeme döngüsü; satın alma talebi, satın alma siparişi, teslim alma, muhasebeleştirme ve ödeme safhalarına bölünerek çalışmada incelenmiştir. Seyahat ve eğlence harcamaları da genellikle satın alma ve ödeme döngüsü içerisinde 
değerlendirilmektedir. İşletmelerin seyahat ve eğlence maliyetlerinin önemli kısmı bireysel olarak satın alma ve ödeme döngüsü içerisinde (\% 75,7), diğer gruplarla paylaşımlı olarak satan alma ve ödeme döngüsünde (\% 9,4), ayrı bir birim olarak (\% $6,8)$ ve personel / bordro döngüsü içerisinde (\% 2,7) değerlendirilmektedir (Schaeffer, 2007a, s. 13).

\section{Satın Alma ve Ödeme Faaliyet Döngüsünde Risklerin Belirlenmesi}

Satın alma ve ödeme faaliyet döngüsü, talep edilen mal ve hizmetlerin tedarikçilerden edinilmesi ve ödemelerin yapılması ile iade ve indirim işlemlerinden oluşmaktadır. İşletmenin çeşitli bölümlerinin işbirliği ile çalışmaları sonucu satın alma ve ödeme işlemleri yerine getirilir.

Risk, beklenenden sapma olasılığıdır. Döngü içerisinde olması beklenen iş ve eylemlerin istenenden farklı olma olasılığı faaliyet riski, finansal risk ve performans riski olarak gerçekleşebilir. Faaliyet riski, iş ve eylemlerin tasarlandığı, yönetildiği, izlendiği ve ölçüldügü şekilden farklı olarak gerçekleşmesidir. İşletmenin faaliyet ile ilgili hedef ve amaçlarına ulaşmadaki iç kontroldeki zayıflığı ve taraflara sunulan hata, hile gibi firsatlardan oluşabilir. Finansal risk, faaliyet riski ve finansal sonuçların yetersizliğinden ve muhasebe uygulamalarının zamanında yapılmaması gibi nedenlerden kaynaklanabilir. Performans riski ise döngü süreci tamamlandığında faaliyet ve finans maliyetlerine bakılmaksızın belirlenen performans göstergelerine ulaşmadaki risktir. $\mathrm{Bu}$ risk, faaliyet ve finans kontrollerinin uygulanmaması ve planlanan eylem gerekliliklerinin yerine getirilmemesi nedeni ile oluşur (Hightower, 2009, s. 31).

Satın alma ve ödeme döngüsünde yapılacak kontrollerin genel olarak temel amacı bu döngüdeki hesapların tam ve doğru şekilde kaydedilmesini sağlamaktır. Bu kapsamda satın almanın altı doğrusu olan; doğru ürünlerin (beklenen mallar ve hizmetler), doğru yerde (istenilen yer), doğru zamanda (istenilen zaman), doğru fiyatta (beklenen fiyat), doğru kalitede (istenilen kalite) ve doğru miktarda (istenen sayıda) alımının gerçekleştirilmesi istenmektedir (Timur, 2013, s. 50). Satın alma kararlarının verilmesi, mal veya hizmetin teslim alınması, ödemenin yapılması, finansal değer hareketlerinin uygun şekilde muhasebeleştirilmesi ve finansal raporların düzenlenmesi suretiyle döngü içerisinde kontrol sağlanmış olmaktadır.

\subsection{Satın Alma Talebinin Yapılmasında Risk Unsurları}

Satın alma talebi, işletmenin her biriminden gelebilmektedir. İşletmelerde satın alma ihtiyacı; stokların belirli düzeyin altına inmesi, müşteri istekleri sebebiyle üretimden gelen istekler, işletmenin ar-ge, pazarlama, yönetim gibi bölümlerinden gelen 
talepler veya maddi duran varlık vb. yatırım planları ile doğabilir (Sevim ve Gül, 2012, s. 98).

Satın alma talebinde istenilen mal veya hizmetin yerindeliği, işletme politika ve prosedürlerine uygunluğu, yer, zaman, fiyat, miktar, kalite ve fonksiyon gibi özellikleri açısından satın alma talebine dönüşmesinde ortaya çıkabilecek bazı risk unsurları aşağıda sıralanmıştır:

- İhtiyaç olunmayan, gereksiz mal veya hizmet için talep olabilir.

- Çifte alımlara neden olabilecek talepler söz konusu olabilir.

- İşletmenin stok politikasına uymayan mal veya hizmetler istenebilir.

- Depo görevlileri ve pazarlama bölümü arasındaki iletişim problemleri olabilir.

- İlgili mal veya hizmetin sağlanması, pazarlanması ve müşteri ilişskilerinde sorunlar olabilir.

- İşletme deposunda yer alacak stokların hangi seviyede yeniden satın alma talebi ile istenmesinde problemler olabilir. Bunun için ekonomik sipariş miktarı, döngü tekniği, ABC yöntemi ve yeni sipariş noktası analizi gibi yöntemler kullanılabilir.

- Yeniden talep düzeyleri stoklar için sürekli güncel tutulmalıdır. Güncellemenin zamanında yapılmaması problem oluşturabilir.

- İşletme içerisinde başlatılan talep, satın alma birimi tarafından istenilen nitelik ve nicelikte sipariş formuna dönüştürülmesindeki farklılıklar da risk içerir.

- Teslim alınan stoklar ilgili yerlerine yerleştirilmediği takdirde mükerrer satın alma taleplerine neden olabilir.

Satın alma talepleri, işletme içerisinde belirlenmiş yetkili kişiler veya birimlerce kabul edilmelidir. İşletme fonksiyonları kapsamında yetkilendirmeler yapılmalı ve "Satın Alma Talep Formu"nun yetkili kişi veya birim tarafından düzenlenerek, satın alma birimine iletilmesi sağlanmalıdır.

\subsection{Satın Alma Siparişinin Verilmesinde Risk Unsurları}

Satın alma talepleri, işletmede ayrı bir bölüm olarak organize edilen "satın alma bölümü” tarafından değerlendirilmelidir. Büyük işletmelerde ayrı bir birim olarak bu birimlerin organize edilmesi mümkünken, küçük işletmelerde bu işlemler belirli kişilerde toplanabilir. Satın alma talebini değerlendiren satın alma bölümü, "Satın Alma Sipariş Formu"nu düzenleyerek uygun tedarikçilerden mal veya hizmetin alınması sürecini başlatmalıdır. Bunun için tedarikçilerin seçimi, mal ve hizmetlerin nitelik ve niceliği gibi hususların belirlenmesi satın alma bölümü tarafından kararlaştırılmalıdır.

Satın alma sipariş formunun düzenlenmesinde ortaya çıkabilecek bazı risklere aşağıda değinilmiştir (Schaeffer, 2007b, s. 18-19):

- Satın alma sipariş formu eksik, yanlış veya parça parça düzenlenmesi, 
- Satın alma sipariş formunun fatura alındıktan sonra düzenlenmesi,

- Satın alma sipariş formlarının ödeme bölümüne gönderilmemesi,

- Güncel listeler üzerinden işlem yapılmaması,

- Satın alma yetkisi olmayan çalışanların işlem yapması,

- Tedarikçilerin satın alma yetkisi olan kişileri bilmemesi,

- Satın alma kartlarının uygun olmayan kişilere verilmesi sonucu gereksiz kullanımların oluşması,

- Satın alma politikalarının tedarikçilere bildirilmemesi,

- Tedarikçilerle satın alma birimi arasında ortaya çıkabilecek komisyon, rüşvet gibi durumlar,

- Tedarikçilerdeki sürekli oluşan kısa dönem fiyat değişiklikleri,

- Tedarikçilerin işletme sistemine kayıt edilmesindeki bazı aksaklıklar aynı satıcının mükerrer kayıt edilmesine veya yanlış kayıtların oluşmasına neden olabilir.

Satın alma isteklerinin belirli personel tarafından yapılması, günlük stok düzeyinin izlenmesi, numaralanmış satın alma istek formlarının kullanılması, satın alma isteklerinin araştırılması ve satın alma için minimum tutarların belirlenmesi gibi önlemlerin alınması riskleri azaltabilir (Bragg, 2007a, s. 329).

\subsection{Mal veya Hizmetin Teslim Alınmasında Risk Unsurları}

Satın alma ve ödeme faaliyet döngüsünün üçüncü safhası teslim almadır. Teslim alma işlemi, ilk safhada işletmenin herhangi bir birimi tarafından talep edilen ve ikinci safhası olan sipariş formu ile tedarikçiden istenilmesi kararlaştırılan mal ve hizmetlerin teslim alınması faaliyetidir. Mal veya hizmetin teslim alınması işletmede ayrı bir bölüm olarak tesis edilecek teslim alma birimi tarafindan gerçekleştirilmelidir. Mal veya hizmetin nitelik ve niceliğini gösteren "Alış Raporu” düzenlenmelidir. Teslim alma işlevi sonunda işletmeye bir borç yükü doğacaktır ki bu işlem döngü içerisindeki kırılma noktasıdır.

$\mathrm{Bu}$ safhada önemli bir husus; teslim alacak birimin istenilen mal veya hizmetle ilgili özelliklerden (miktar, fiyat, fonksiyon, kalite...) önceden haberdar olmalı mı olmamalı mı sorusudur. Buradaki risk, ilgili birim teslim alınacak mal veya hizmetin özelliklerinden önceden haberdar olması durumunda teslim alma işlevini özen göstermeden gerçekleştirebilmesidir. Haberdar olmaması durumunda ise ilgisiz ürünlerin teslim alınması gibi sorunlar sözkonusu olabilir.

Mal veya hizmetin teslim alınmasında oluşabilecek bazı aksaklıklar şunlardır: (Schaeffer, 2007b, s. 43).

- İşletmeye ürünü kimin sipariş ettiği belli olmayan faturaların gelmesi mümkündür. Bu gibi durumlarda siparişi veren kişi veya birim bulunmalı ve fatura onay için ilgili kişiye/birime gönderilmelidir. 
- İşletmenin istediği zamanda teslim gerçekleşmeyebilir.

- Mal veya hizmet istenilen nitelik ve nicelikte olmayabilir.

- Mal ve hizmetin teslim alındığı onayı ile faturanın kabulü hangi birimlerde gerçekleşeceği ve ödeme işleminin ne zaman yapılacağı konusunda riskler mevcuttur.

- Sipariş edenin belirli olmadığı faturalar işletmeye gelebilir.

\subsection{Muhasebeleştirmede Risk Unsurları}

İşletmenin içerisinde yer alan iç kontrol sistemi ile ilgili "satın alma talep formu", "satın alma sipariş formu", "alış raporu” gibi belgeler muhasebeleştirme için gerekli belgeler değildir. Muhasebeleştirme için gerekli belge faturadır. Faturanın muhasebe bölümüne ulaşmaması durumunda muhasebe kayıtlarının zamanında yapılmaması riski doğmaktadır. Finansal tablolar üzerinde yöneticilerin savları ancak muhasebe kayıtlarının doğru ve dürüst olarak yapılmasına bağlıdır. Finansal raporlarda sunulan varlık, borç, özkaynak, gelir, gider ve maliyet tutarlarının gerçekten işletmede var olması ve doğru değerlerle gösterilmesi döngünün etkin bir şekilde işleyişi ile sağlanabilmektedir. Teslim alınan mal ve hizmetlere ilişkin eksiklik ve yanlışlıklar, dönem sonu envanter işlemleri sürecinde bazı farklılıkların doğmasına neden olur. Satın alma birimi ve ödeme birimlerinin tedarikçilerle olan doğrudan ilişkileri muhasebe biriminin yapmış olduğu borç/alacak mutabakatları ile aynı sonucu vermeyebilir. Ödeme birimlerinin yapmış oldukları ödemelerin zamanında muhasebe kayıtlarına aktarılamaması kasa farklarını, satın alınan mal veya hizmetler ile faturanın eş zamanlı işlem görmemesi de stok sayım farklarını oluşturabilir.

\subsection{Borcun Ödenmesinde Risk Unsurları}

$\mathrm{Bu}$ döngünün son safhasıdır. Borç ödemesi yapacak kişi yada bölüm, işletme içerisinde ayrı ve yetkili birimler aracılığıyla yerine getirilmelidir. Satın alma biriminin teslim aldığı ürünlerin sipariş edilenlerle aynı olup olmadığı ve ödeme birimine ulaştırılmaması yanlış ödemelere neden olabilmektedir. Satın alma biriminin anlaştığ fiyat, miktar, iade ve indirim hususları ödeme birimine ulaştırılamayabilir. Faturaların kopyaları ile işlem yapılırsa, yanlış ve mükerrer ödemeler olabilir. Satın alma birimi ile ödeme birimi arasında sıkça anlaşmazlık oluşur. $\mathrm{Bu}$ iki birim arasındaki iletişim zayıflığı mükerrer ödemeler, indirimlerin kaçırılması vb. mali problemler oluşturabilir. Mükerrer ödemeler genellikle faturanın doğru kişiye ulaşmamasından kaynaklanmaktadır. Tedarikçi, aynı teslim ile ilgili farklı zamanlarda birden fazla fatura göndermek suretiyle işletme içindeki iletişim eksikliğinden faydalanarak satıcı hilesine neden olabilir. İkinci faturayı gönderen satıcılar, tarih ve numara değişikliği yaparak hileye başvurabilir. Sipariş formu ve alış raporu olmayan faturalara gereksiz ödemeler yapılabilmektedir. Satın alma kartları ile stok ve maddi duran varlık alınmasına izin verilmemelidir (Bragg, 2007b, s. 26-27). 
Satıcının alacağını erken tahsil etmek istemesi, işletmenin de borcunu mümkün olan en geç sürede ödemek istemesi likidite sorunu oluşturabilmektedir. Dolayısıyla satın alma ve ödeme politika ve prosedürleri tedarikçilerle karşılıklı anlaşılarak yapılmalıdır. Satıcılardan gelen şikayetler dikkatle incelenmelidir. İşletme çalışanı, satıcıya yapılması gereken ödemeyi kendi menfaati doğrultusunda kullanabilmektedir. Aynı zamanda çalışan-satıcı işbirliği, işletmeden gereksiz ödemelerin yapılmasına neden olabilir.

\section{Satın Alma ve Ödeme Faaliyet Döngüsünde Risklere Verilebilecek Karşılıklar}

Satın alma ve ödeme faaliyet döngüsünde olası riskler sonucu hata ve hileler işletmeyi zarara uğratabilmektedir. Bu riskleri engelleyebilecek etkin bir iç kontrol sisteminin tasarlanması ve uygulanabilmesi; belgeleme ve muhasebe kayıt düzeni, görevlerin ayrılığı, yetkilendirme, fiziksel kontrol ve bağımsız mutabakat başlıkları altında incelenecektir (Güredin, 2007: 329). Bu faaliyetlerin tamamı manuel ortamda yapılabileceği gibi günümüzde çoğu işletmelerin uyguladığı şekilde elektronik ortamda yapılması da mümkündür.

Satın alma ve ödeme faaliyetlerine ilişkin öncelikle iş akışı oluşturulmalıdır. Bu akış şemasında her bir aşamada yapılması gerekli işlemler ayrıntılı olarak belirtilmelidir. Her bölümün ve çalışanın sorumluluğu ve yetkisi belirlenmelidir (Sevim ve Gül, 2012, s. 112).

\subsection{Belgeleme ve Muhasebe Kayıt Düzeni:}

Bu döngü kapsamında kullanımı zorunlu yasal belgeler ile isteğe bağlı belgeler, iş ve işlemlerin akışında önemli faydalar sağlamaktadır. Satın alma ve ödeme faaliyet döngüsünde kullanılabilecek belgelerden bazıları aşağıda açıklanmıştır: (Schaeffer, 2002, ss. 12-14; Schaeffer, 2004, ss. 3-8; Schaeffer, 2007b, ss. 21-23).

a) Satın Alma Talep Formu: İhtiyaç olunan bir mal veya hizmetin yetkili ve uygun personel tarafından düzenlenerek satın alma bölümüne iletildiği belgedir.

b) Satın Alma Sipariş Formu: Satın alma talep formunda yer alan bilgilerin uygun ve belirli tedarikçilerinden temini için satın alma bölümü tarafından düzenlenen belgedir.

c) Alış Raporu: Satıcıların sipariş formuna göre işletmeye getirdiği mal veya hizmetlerin özelliklerini (miktar, fiyat, kalite, fonksiyon...) içeren ve işletmenin teslim alma bölümünün düzenlediği belgedir.

d) Alış Faturası: Satıcı tarafından düzenlenen alıcı işletmeye gönderilen vergi mevzuatına göre düzenlenmesi zorunlu belgedir. Müşteri firmanın borç tutarını gösterir. 
e) Alım Dosyası: Sözkonusu mal veya hizmet alımı ile ilgili oluşturulan ve bu süreç içerisindeki tüm bilgilerin toplandığı dosyadır.

f) Alış İşlemleri Dosyası: Satın alma ve ödeme faaliyet döngüsüyle ilgili tüm bilgilerin yer aldığı dosyadır. Bu dosyada alım işlemi için uygun görülen satıcılar, mal ve hizmetlerin özellikleri gibi bilgiler bulunur.

g) Ödeme Dosyası: Muhasebe sistemi tarafindan yapılan bütün ödeme işlemlerini içerir.

h) Ticari Borç Mizanı: Satıcılara olan borçları gösterir.

1) Satıcı Raporu: Her bir satıcının açılış bakiyesi, alımlar, iade/iskontolar, ödemeler ve kapanış bakiyelerini gösteren rapordur.

Belgeleme, ödeme işlemlerinin gerçekleşmesinde önemli bir aşamadır. Belgelerin yasal düzenlemeler ve işletme politikaları doğrultusunda uygun bir şekilde düzenlenmesi sağlanmalıdır. Ancak, firma çalışanları işletme varlıklarını şahsi menfaatleri doğrultusunda kullanabilmektedir. Bu haksız menfaat temini işlemi, işletme faaliyeti kapsamında belgelendikten sonra, firma tarafından ödenmektedir. Bu durum sadece çalışanlar tarafından değil; aynı zamanda firma sahipleri, ortakları, akrabaları gibi kişilercede uygulanabilmektedir (Wells, 2011, s. 107).

Geçerli ve uygun ticari işlemden doğan borçlar tam ve doğru olarak kayıtlara geçirilmelidir. Kaydedilecek ticari borç tutarı "satıcı faturası"na uygun olarak "onaylı satın alma sipariş formu" ve "alış raporu" ile uyumlu olmalıdır. Satıcıdan orijinal faturaları doğrudan işletmenin belirlediği birime (ödeme bölümü, satın alma birimi, muhasebe veya farklı bir birim) gönderilmesi istenilmelidir. Faturanın gelmesinde iki senaryo bulunmaktadır. Birincisi, satıc1 faturas1 ödemeyi yapacak birime gönderilmelidir. Bu seçenekte ödemeyi yapacak birime ulaşan satın alma sipariş formu, alış raporu ile fatura karşılaştırması sonucu ödemenin yapılması gerçekleştirilmektedir. Ödemenin yapılması bu seçenekte hızlı bir şekilde yapılır. İkinci seçenekte ise; fatura, satın alma görevlisince teslim alınmalıdır. $\mathrm{Bu}$ durumda satıcıya yapılan ödemelerde gecikme olabilir. $\mathrm{Bu}$ seçeneğin tercih edilmesi halinde faturanın hızlı bir şekilde ödemeyi yapacak birime ulaştırılması sağlanmalıdır (Schaeffer, 2007b, s. 9-10).

\subsection{Görevlerin Ayrılı̆ğ}

İşletme içerisinde bir işin başlangıcından sonuna kadar aynı kişi/birim tarafından yapılmaması, söz konusu işin evrelere bölünerek farklı birimlerce gerçekleştirilmesi görevlerin ayrılığı ilkesi gereğidir. Bu ilke gereğince işletme içerisinde bazı kişilerin kapalı bir döngü içerisinde hata ve hile yapmalarının önüne geçilmesi amaçlanmaktadır. 
Bu döngü içerisinde yer alan yukarıda açıklanan safhalar, görevlerin ayrılığı ilkesi gereğince organize edilmeli ve işleyişi sağlanmalıdır. Satın alma talebi işletme içerisinde ilgili her birimden gelebilir. Her birimden sorumlu ve yetkili kişilerin belirlenmesi sağlanmalıdır. Bu döngü kapsamında, satın alma talepleri, yetkili kişilerce satın alma bölümüne iletilmelidir. Satın alma bölümü, satın alma taleplerini incelemelidir. $\mathrm{Bu}$ incelemede; yer, zaman, miktar, fiyat, fonksiyon, kalite gibi özellikleri açısından değerlendirme yapılarak, satın alma sipariş formu ile uygun satıcılardan temini için harekete geçilmelidir. Satıcılar, ürünleri işletmenin ayrı bir bölümü olan teslim alma bölümüne getirmelidirler. Teslim alma bölümü, teslim aldığ mal veya hizmetleri "alış raporu" ile tespit etmelidir. Bu rapor, ilgili bölümlere (satın alma bölümü, ödeme bölümü, teslim alma bölümü...) dağıtılarak işletme içerisinde tam ve doğru bilgi akışının sağlanmasına katkıda bulunulmalıdır. Ödeme bölümü ise satın alma talep formu, satın alma sipariş formu, alış raporu ve satıcı faturasına göre ödemeyi gerçekleştirmelidir. Muhasebeleştirme de faturaya uygun şekilde yapılmalıdır. Ancak işletmenin isteğe bağlı kullandığı belgelerin de destekleyici doküman olarak muhasebe kayıtlarının yapılmasına faydaları bulunmaktadır. Bu şekilde görevlerin farklı safhalarda farklı kişi/birim tarafindan yerine getirilmesi hata ve hile risklerinin azalmasına katkıda bulunmaktadır.

Ticari borç işlemleri; satın alma ve teslim alma fonksiyonlarından bağımsız personel tarafından kaydedilmelidir. Ticari borç ödemeleri nakit, çek, senet, banka aracılığı vb. şekillerde yapılabilir.

\subsection{Yetkilendirme}

Mal ve hizmetlerin ihtiyaç olup olmadığının tespiti yetkili personel/birimler aracılığıyla yapılmalıdır. Stok siparişi için işletme politikalarına göre asgari miktar belirlenmelidir. Bunun için ABC yöntemi, döngü yöntemi, yeni sipariş noktası analizi, ekonomik sipariş miktarı gibi yöntemler ve işletme deneyimlerinden yararlanılabilir. Satın alma talebi periyodik veya periyodik olmayan şekilde yapılabilir. Satın alma taahhüdünün onaylanabilmesi için yetkili kişilerin onayı alınmalıdır. Yetkili kişi/birim; uygun satıcının belirlenmesi, yeterli miktarda ve özellikte sipariş, uygun fiyat ve kalite, uygun zamanda teslim ve ödeme gibi satın alma ile ilgili bir piyasa araştırması yapmalıdır. Alternatif satıcılar, uzun dönemli ihtiyaç analizleri, uzun dönemli sözleşmelerin yapılması yetkili personel/birim tarafından değerlendirilmelidir. Satıcıların performansı değerlendirilerek yeni siparişlerde dikkate alınmalıdır. Örneğin; belirli tutarlara göre satın alma onayı için yetkilendirme yapılabilir. 10.000 TL'ye kadar bölüm yöneticisi, 10.001-25.000 TL'ye kadar faaliyet yöneticisi yardımcıs1, 25.001 TL'den fazlası için faaliyet şefinin onayının alınması sağlanabilir (Bragg, 2009, s. 43). 
Satın alma sipariş formunun orjinali satıcıya, bir nüshasi satın alma bölümüne, bir nüshası teslim alma bölümüne ve bir nüshası da ticari borçların izlendiği bölüme gönderilmelidir. Hizmet satın alımında sipariş formu veya sözleşmeye uygun olarak işlemin yapıldığına dair ilgili bölüm tarafından kontrol sağlanmalıdır. Sürekli çalışılan tedarikçikler için otomatik ödeme şekilleri (her ay belirli zamanlarda belirli tutarda ödeme) tercih edilebilir. Bu durumda da ödemenin yapılma nedeni ortadan kalktığında bile sistemin ödemeye devam etmesi riski bulunmaktadır. Bunun için yapılan ödemelerde belirli bir bitiş tarihi sisteme eklenerek kontrol mekanizması sağlanabilir.

Satıcılar teslim ettikleri mal ve hizmetlere karşılık olan alacaklarının ödenmesinde gecikme olduğuna dair itirazları olabilmektedir. İşletme içerisinde bu durumun nedeni araştırılmalıdır. Genellikle gecikmenin nedeni belirlenen politika ve prosedürlerin tamamlanmamış olmasıdır. Bu noktada satıcı faturasının doğrudan ödeme bölümüne gönderilmesi istenilmelidir. Ödemenin gerçekleşmesi için mutlaka üçlü karşılaştırma yapılmalıdır. Satın alma sipariş formu, alış raporu ve satıcı faturasının karşılaştırılması "üçlü karş1laştırma” işlemidir (Bragg, 2007b, s. 31).

İşletmelerde farklı ödeme birimlerinin olması bir işlem için farklı ödemelerin yapılmasına ve gereksiz ödemelerin yapılarak işletmeden nakit çıkışlarının artmasına neden olabilmektedir. Bunun için ödeme işlemleri merkezileştirilerek gereksiz ödemelerin yapılması önlenebilir (Bragg, 2007b, s. 48-49).

\subsection{Fiziksel Kontroller ve Erişim Kısıtlaması}

Yetkili ve sorumlu kişilerce mal ve hizmetin teslim alınması ve korunması sağlanmalıdır. Aynı zamanda, bu döngüde yer alan bilgi, belge ve iş akışının sadece sorumlu kişilerce kullanılması sağlanmalıdır. Özellikle elektronik ortamda yapılacak işletme içi bilgi akışında gerekli önlemler alınarak, yetkisiz kişi ve birimlerin erişimi kısıtlanmalıdır. İşletme çalışanları, yetkisi dahilinde olan işlemleri yapabilmeli, değiştirebilmeli ve izleyebilmelidir. Yetkilendirme geniş tutulduğu takdirde, kullanıcı bilmeyerek veya kasıtlı olarak diğer süreçleri etkilemek suretiyle risk oluşturabilir (Sevim ve Gül, 2012, s. 116).

Mal veya hizmetin teslim alınması esnasında kontrol mekanizması sağlanmalıdır. Teslim alma bölümü uygun olmayan satın alma sipariş formlarına gelen stokları teslim almamalıdır. Teslim alma bölümü, mal veya hizmetin satın alma sipariş formundaki kriterlere uygunluğunu belirleyerek teslim almalıdır. Bu durumu alış raporu ile belgeleyerek, uygun olmayan durumlar bu raporda belirtilmelidir. Söz konusu belgenin bir nüshası teslim alma bölümünde kalmalı, bir nüshası satın alma bölümüne bir nüshası da ticari borçların izlendiği bölüme gönderilmelidir. 
Teslim alma bölümü, satın alma sipariş formunda yer alan bilgileri öğrenerek mal veya hizmetleri teslim aldı̆̆ takdirde sayım işleminde dikkat ve özen göstermeyebilir. Bunu engeleyebilmek iyi bir uygulama şu şekilde tasarlanabilir: Elektronik ortamda teslim alma bölümünün öncelikle ilgili sütuna satıcıdan gelen mal veya hizmetleri bilgi sistemine girmesi istenebilir. Daha sonra ilgili sütun yanında açılacak yeni bir sütunda satın alma sipariş formu bilgilerinin gelmesi sağlanır. Üçüncü sütunda ise satın alma sipariş formu ile teslim alma bölümünün tespit ettiği bilgiler arasındaki farklar sistem tarafından otomatik olarak görülebilir.

Uygunsuz malzeme geldiğini belirleyen teslim alma bölümü ret raporu düzenleyerek iade işlemlerini gerçekleştirmelidir. Malların satıcılara geri gönderilmesi için kontrol mekanizması, belgeler ve kayıt işlemleri için politika ve prosedürler belirlenmeli ve satıcılarla mutabakat halinde işlemler tamamlanmalıdır.

\subsection{Bağımsız Mutabakat}

Farklı safhalara ayrılan satın alma ve ödeme faaliyet döngüsünde bu faaliyetlerin birbirinden bağımsız şekilde yapılması sağlanmalıdır. Birbiriyle entegre olan bu safhalar, her faaliyetini belgelemeli ve bir birim diğeri üzerinde baskı unsuru oluşturmamalıdır. İşletme içi bağımsız mutabakat sağlandığı kadar işletme dışı ilgili taraflarla da (satıcılar, bankalar, nakliye firmaları...) belirli zaman aralıklarında bilgi alışverişinde bulunulmalıdır.

$\mathrm{Bu}$ döngü içerisinde, ödemenin yapılması ayrı bir kırılma noktasıdır. Ayrı birim olarak organize edilen ödeme bölümü üçlü karşılaştırma yaparak ödemeyi gerçekleştirmelidir. Satın alma sipariş fişi, alış raporu ve satıcı faturasının üçlü karşılaştırılması sonucu ancak ödeme yapılmalıdır (Bragg, 2007b,s. 18; Schaeffer, 2002, s. 14).

Döngü kapsamındaki politika ve prosedürlerin karmaşıklığı iş akışında sorunlar oluşturabilir. Bunun için gereksiz onaylardan kaçınmalı, ödemenin mutlaka onay temel alınarak yapılması sağlanmalı, faturalar doğrudan ödeme bölümüne gönderilmeli, üçlü karşılaştırma (satın alma sipariş formu, alış raporu, fatura) mutlaka yapılmalı, tedarikçiler fatura üzerine işletmenin belirlediği kodları yazması sağlanmalıdır (Bragg, 2007b, s. 24-25).

\section{Satın Alma ve Ödeme Faaliyet Döngüsünde Hile}

Hile, oldukça geniş bir kavram olmakla birlikte; işletme bünyesinde yer alan birisinin işletme varlık ve kaynaklarını bilinçli, gizli ve kasıtlı bir şekilde kullanması veya ele geçirerek haksız menfaat sağlaması olarak tanımlanabilir (Bozkurt, 2009, s. $60)$. Hile riskinin belirlenmesi, hileyi oluşturan teşvik, baskı, fursat ve haklı gösterme gibi nedenlerin değerlendirilmesini kapsar (Özkul ve Özdemir, 2011, s. 62). 
Hilede kasıt unsuru bulunması nedeniyle tespiti zor ve karmaşıktır. Bağımsız denetim hilelerin ortaya çıkarılmasında yetersiz kaldı̆̆ 1 yapılan araştırmalarda görülmektedir. ACFE'nin 2014 raporuna göre (ACFE 2014 Report to the Nations on Occupational Fraud and Abuse) işletmelerde meydana gelen hilelerin yalnızca \% 3'ü (2010'da \% 4,6 ve 2012'de \% 3,3'ü) bağımsız denetim yoluyla belirlenebilmiştir. Bağımsız denetimin hileleri ortaya çıkarmaktaki başarısızlığı, denetim faaliyetinin sadece hileleri ortaya çıkarmak için tasarlanmamış olmasından kaynakmaktadır. İşletmelerin gelişen ve giderek karmaşıklaşan yapısı nedeniyle de hilelerin ortaya çıkarılmasına yönelik özel bir çalışmanın yapılması gereklidir.

Satın alma ve ödeme döngüsü, yapısı gereği hile riski yüksek bir döngüdür. ACFE 2010 Raporuna göre işletmelerde meydana gelen hilelerin \% 54,5'i bu döngü dahilinde gerçekleşen hilelerden oluşmaktadır (Fatura Hileleri \% 26, Gider Hileleri \% 15,1, Çek Hileleri \% 13,4). Bu nedenle satın alma ve ödeme faaliyet döngüsünde risklerin belirlenmesi ve kontrollerin etkin bir şekilde uygulanması işletmeler üzerinde doğruluk ve güvenirlik faktörüne olumlu katkı sağlayacaktır.

Stoklara ilişkin hileli finansal raporlama bilgileri arasında; satın alınan malların değerinin düşük gösterilmesi, dönemler arası geçişler yapılması, satın alınan malın hiç kayıt altına alınmaması, satıcıdan alınan indirimler neticesinde stok maliyetlerinin azaltılmaması, envanterde aynı malların birden fazla sayılması, hayali stokların muhasebeleştirilmesi, stok değer düşüklüklerinin muhasebeleştirilmemesi gibi hileler yer almaktadir (Mengi, 2013b, s. 99).

Genel olarak hile çeşitleri arasında; çalışan yolsuzluğu, yönetici hilesi, yatırımcı yatırımcı dolandırıcılığı, satıcı ve müşteri hilesi bulunmaktadır (Albrecth vd., 2006, s. 11). Satın alma ve ödeme döngüsünde yapılan hileler, hileyi yapanlar açısından üç başlık altında aşağıda açıklanmıştır:

a) Çalışanlar tarafından yapılan hileler: Hayali satıcılarla işlem yapılması, siparişlerin parçalara ayrılarak onaydan kaçırılması, yetkisiz alımlar yapılması vb. fırsatları değerlendiren çalışanlar hileye başvurabilmektedir. $\mathrm{Bu}$ hile türünün önlenebilmesi için işletme çalışanlarının etik ilkelere sahip olabilmesi gerekir. Bunun için öncelikle işletmede kurumsal yönetim anlayışı bulunmalıdır. İşletme faaliyetlerine yönelik politika ve prosedürler kurum kültürü ile yerleşmiş olmalıdır.

b) Satıcılar tarafından yapılan hileler: Kalitesiz malların işletmeye gönderilmesi, yüksek fiyatlı pazarlama, çift faturalama gibi hilelerle satıcılar işletmede yer alan iç kontrol mekanizmasının yetersizliğinden faydalanabilmektedir. İşletmenin satın alma yapacağı tedarikçiler seçilirken, işletme ile satıcı arasında etik kurallar öncelikle müzakere edilmelidir. 
c) Çalışan-satıcı ve çalışan-çalışan işbirliği: Satıcı ile çalışan arasında gerçekleştirilen işbirliği neticesinde işletme için gereksiz alımların yapılması, yüksek fiyatlı işlemler, alımların belirli satıcılara yönlendirilmesi gibi hileler görülebilmektedir. İşbirliği içinde gerçekleştirilen hilelerin ortaya çıkma süresi uzadıcça işletmeye çok büyük zararlar vermektedir. Örneğin, satıcı ile anlaşan bir çalışan karşılıklı menfaat ilişkisi çerçevesinde hayali bir işleme ait fatura düzenlenmesi suretiyle işletmeden nakit çıkışı sağlayabilir. Bununla birlikte, uygun kalite, fiyat, koşul ile işletmeye mal veya hizmet alımını gerçekleştiren çalışan, satıcı ile işbirliği halinde ise gelecekte firsat yakaladığında işletmeyi büyük zararlara uğratabilir (Mengi, 2013a, s. 128).

Hileler, satın alma ve ödeme faaliyet döngüsünde direkt veya endirekt olarak görülmektedir. Bu döngü kapsamında yer alan hile türleri çek hilesi, fatura hilesi ve gider hilesi olarak aşağıda açıklanmıştır.

\section{1. Çek Hileleri}

İşletmelerin çek vb. ödeme araçlarıyla olan polita ve prosedürlerinin tasarlanışı ve işleyişinde yer alan aksaklıklar kolay yapılabilen çek hilelerine kaynak oluşturmaktadır. Özellikle görevlerin ayrılığı ilkesinin küçük işletmelerde gerektiği gibi uygulanamaması çek hilelerinin bu işletmelerde daha yoğun görülmesine neden olmaktadır. İşletme çalışanı, kendi faydasına hazırladığı çeki kullanarak veya bir başkası için düzenlenen çeke el koyarak bu hileyi gerçekleştirebilmektedir. İşletme çalışanı çek defterine, banka kayıtlarına, çek bilgilerini değiştirme yetisine kolayca erişebilmesi, sahte imza atabilmesi bu hiledeki firsatlardandır. İşletme çalışanı sahte çek düzenleyerek ilgisiz kişi ve firmalara gereksiz ödemelerin yapılmasına neden olabilir. Çalışan, çekin ciro edilmesi aşamasında gerçek alacaklı yerine uygunsuz kişi ve firmalara ciro yaparak sahte ciro hilesi de yapabilir. Çalışan çekte yer alan alacaklı isim yerine uygun olmayan kişi veya firmaları yazarak değiştirilmiş çek alacaklısı hilesine de başvurabilir. Çeklerle ilgili bazı hile belirtileri arasında; ardışık günler arasında eksik çekin bulunması, bankadan gelen ekstelerde yapılan değişiklikler, ödendiği halde bankadan gelen bilgilerde ödeme bilgisi olmayan çekler, çek ödemeleri ile ilgili satıcı şikayetleri, çift çek ödemeleri, diğer belgelerle desteklenmeyen çek ödemeleri, banka ve satıcılarla yapılan mutabakatlardaki tutarsızlıklar gibi nedenler yer almaktadır. (Bozkurt, 2009, s. 268-279; Schaeffer, 2007b, ss. 181-186).

\subsection{Fatura Hileleri}

Fatura hileleri ile üzerinde hile yapılan işletmeler çoğunlukla gerçekte var olmayan işletmeler aracılığıyla yüksek tutarlı veya gereksiz mal ve hizmet satın almak durumunda kalmaktadır. Kağıt üzerinde kurulan sahte bir işletmeyle mal veya hizmet alış verişi yapılmış gibi gösterilerek hile yapılmaktadır. Tedarikçilerden daha uygun fiyata alınabilecek mal veya hizmetler doğrudan alınmayıp, aracı işletmeler kurulması 
suretiyle bu işletmelerden daha yüksek fiyatla alınarak kurban işletmenin satın alma işleminde zarar etmesi ve aracı işletmeye karın aktarılması hile yapanlar tarafindan sıkça başvurulan bir hile yöntemidir. Gerçekte var olan satıcıların işletme çalışanları ile işbirliği yapması sonucu yüksek tutarlarla mal ve hizmet faturası düzenlenerek ilgili işletmeden haksız kazançlar sağlanabilmektedir. Yanı sıra, işletme çalışanı kendi menfaati için satın aldığı veya kullandığı mal ve hizmet bedelini işletme adına fatura düzenlenmesi suretiyle işletmeden gereksiz ödemelerin yapılmasına neden olabilmektedir (Schaeffer, 2007b, 195; Bozkurt, 2009, s. 216, 217).

$\mathrm{Bu}$ hilenin belirtileri arasında; faturaların olağan bilgilerindeki eksiklikler, normalden yüksek fiyat hareketleri, ödemelerin kurumlar yerine kişilere yapılması, aynı satıcı faturalarında farklı bilgiler bulunması, belirli tedarikçi faturalarındaki yüksek miktarlı alımlar sayılabilir (Bozkurt, 2009, s. 244, 245).

\subsection{Gider Hileleri}

$\mathrm{Bu}$ hile türünde çalışanlar işletmede yaptıkları giderler ile ilgili bilgiler üzerinde oynayarak, kendilerine haksız kazanç sağlamaya çalışırlar. Gider hileleri arasında niteliği değiştirilmiş giderler ile işletmeden haksız para alma, olağan giderlerin abartılarak belgelenmesi suretiyle işletmeden haksız para temini, gerçekte olmayan işlemlere ilişkin sahte belgeler bulunması suretiyle işletmeden para alımı yer almaktadır. Ayrıca tek kalemde yapılabilecek bazı giderler parçalara bölünerek haksız para temini sağlanabilmektedir (Bozkurt, 2009, s. 279-293).

Gider hilelerinin yapılma şekilleri içerisinde çalışanın izinli olduğu günlerde ödeme talebinde bulunması, ödemeyi yapan kişinin aynı zamanda gideri gerçekleştiren kişi olması, eksik veya orijinal olmayan belgelere dayanarak ödeme yapılması, harcama için tanımlanan sınırlara yakın tutarlarda seyreden giderler sayılabilir.

\section{Sonuç}

Satın alma ve ödeme faaliyet döngüsü, işletme yapısı içerisinde hata ve hile riskine maruz kalan bir döngü olduğu yapılan saha araştırmalarından anlaşılmaktadır. Hata ve hile riskini minimum düzeye düşürebilmenin yolu etkin bir iç kontrol mekanizması oluşturmak ve uygulamaktır. İşletme yönetimi, gerek işletme içi taraflar gerekse işletme dışı taraflarla olan iş ve işlemlerine ilişkin politika ve prosedürler belirlemelidir. İç kontrol sisteminin oluşturulması, işletmenin sahip ve ortakları, yönetimi, çalışanları ve işletme ile ilgili tarafların birlikte yapacakları ve sürekli güncel halde tutacakları ortak çalışma ile mümkündür.

Satın alma ve ödeme faaliyet döngüsüne ilişkin iç kontrol sisteminin oluşturulması, beş aşamalı olarak gerçekleştirilebilir. Bu kapsamda döngünün safhaları; satın alma talebinin oluşturulması, satın alma sipariş formunun düzenlenmesi, teslim 
alma işlevi, muhasebeleştirme ve ödeme başlıkları altında gruplanarak oluşturulabilir. Her bir safha içerisinde meydana gelebilecek olası riskler belirlenmeli ve risklere işletmenin vereceği karşılıklar hazırlanmalıdır. Her bir safhanın farklı kişi veya birim tarafından yerine getirilmesi olan görevlerin ayrılığı ilkesi, yetkili kişi/birimlerce işlemin yapılması, her bir işlemin belgeye dayandırılması, mal veya hizmetin teslim alınması ve korunmasında gerekli özenin gösterilmesi, muhasebe kayıtlarının gerçeğe uygun şekilde yapılabilmesi ve işletmeden yapılan ödemelerin satın alma amaçlarına uygun şekilde gerçekleştirilmesi gibi işlevler yazılı olarak ilgililere tebliğ edilmelidir. Görev ve sorumlulukları belirlenen personelin de satın alma ve ödeme faaliyet döngüsüne ilişkin iş ve işlem akışında işletme amaçlarına uygun hareket etmesi sağlanmalıdır. İşletme içi ve dışı tarafların bu döngü kapsamında sürekli iletişim halinde olmaları ve birbirleriyle bağımsız bir şekilde mutabakat sağlamaları da döngünün işleyiş etkinliğini ve güvenirliğini artıracaktır.

Finansal tabloların bağımsız denetiminde, finansal raporların doğruluk, dürüstlük ve güvenirlik derecesini belirleyen en önemli etmenlerden biri olan işletmenin iç kontrol sistemi değerlendirilmektedir. Etkin ve verimli bir şekilde tasarlanan ve işleyen bir iç kontrol sisteminde bağımsız denetim faaliyetinin sonuçlarına güven daha da artacak, bağımsız denetim süresi kısalacak ve denetim maliyeti azalacaktır. Bununla birlikte çalışanların, satıcıların ve çalışan-çalışan, çalışan-satıcı işbirliği ile işletme üzerinde görülebilecek çek hilesi, fatura hilesi ve gider hilesi gibi hilelerden işletmenin arındırılmasına önemli katkılar sağlayacaktır. 


\section{Kaynakça}

ACFE, (2010). Report to the Nations on Occupational Fraud and Abuse.

ACFE, (2014). Report to the Nations on Occupational Fraud and Abuse.

Akbulut, E., (2012). "İşletmelerde İç Kontrol Sisteminin Etkinliğinin İncelenmesi ve Trakya Bölgesindeki Ayçiçek Yağı Sektöründe Bir Araştırma”, Electronic Journal of Vocational Colleges, 174-187.

Aksoy, T., (2007). Basel II ve İç Kontrol, Ankara SMMM Odası Yayın No 53, Ankara.

Akyel, R., (2010). “Günümüzde İç Kontrol Anlayışı ve Türkiye’ye Yansıması”, Amme İdaresi Dergisi, Cilt 43, Say1 4, 167-191.

Albrecht P.S., Albrecht C.C., Albrecht C.O., (2006). Fraud Examination, Thomson, Canada.

Atmaca, M., (2012). "Muhasebe Skandallarının Önlenmesinde İç Kontrol Sisteminin Etkinleştirilmesi", Afyon Kocatepe Üniv. İ.İ.B.F. Dergisi, Cilt 14, Sayı 1, 191205.

Bozkurt, N., (2006). Muhasebe Denetimi, Alfa Yayınevi, İstanbul.

Bozkurt, N., (2009). İşletmelerin Kara Deliği Hile, Alfa Yayınevi, İstanbul.

Bragg S. M., (2007a). Accounting Policies and Procedures Manuel, John Wiley \& Sons, New Jersey.

Bragg, S. M., (2007b). Accounting Best Practices, John Wiley \& Sons, New Jersey.

Bragg S. M., (2009). Accounting Control, John Wiley \& Sons, New Jersey.

Ceran, Y., Bezirci, M., (2011). "Stok Hesaplarının Denetiminde İç Kontrol Sistemi ve İç Denetimin Önemi”, Sosyal ve Ekonomik Araştırmalar Dergisi, Sayı 22, $507-$ 535.

Ceyhan, İ. F., Apan, M., (2014). “COSO İç Kontrol Modeli’nin Yapısal Eşitlik Modeli ile İncelenmesi: Bir Hastane Uygulaması", Mehmet Akif Ersoy Ü. Sosyal Bilimler Enstitüsü Dergisi, Cilt 6, Say1 10, 179-198.

Dabbağolu, K., (2009). “İç Kontrol Sistemi”, Journal of Qafqaz University, Sayı 26, 109-115.

Demirbaş, M., (2005). “İç Kontrol ve İç Denetim Faaliyetlerinin Kapsamında Meydana Gelen Değişimler”, İstanbul Ticaret Ü. Sosyal Bilimler Dergisi, Y1l 4, Sayı 7, 167-188.

Demirbaş, M., (2008). "Public Company Accounting Oversight Board'a Göre İç Kontrol Birimlerinin Faaliyetlerinde Yönetimin Sorumlulukları ve Denetçi Raporları, Muhasebe Bilim Dünyası Dergisi, 2008/4, 37-66.

Ellram L. M., Siferd S. P., (1993). Purchasing: The Cornerstone of The Total Cost of Ownership Concept, Journal of Business Logistics, Vol. 14, No. 1, 163-184.

Erol, M., (2008). "İşletmelerde Yaşanan Yolsuzluklara Karşı Denetimden Beklentiler”, Süleyman Demirel Ü. İİBF Dergisi, Cilt 13, Say1 1, 229-237.

Göçen, C. A., (2010). "Kurumsal Yönetim, İç Kontrol ve Bağımsız Denetim: Parmalat Vakası", Mali Çözüm, Say1 97, 107-129.

Gönen, S., (2009). "İç Kontrol Sisteminin Unsurlarından Kontrol Ortamının İncelenmesine Yönelik Bir Araştırma”, Muhasebe Bilim Dünyası Dergisi, 2009/1, 189-217. 
Güner, M. F., (2009). "Kamu İdarelerinin Etkin Yönetiminde İç Kontrol Uygulamalarının Rolü”, Maliye Dergisi, Sayı 157, 183-195.

Güner, M. F., (2010). "Kontrol Ortamının Değerlendirilmesi: Bir Kamu İdaresinde Uygulama", Muhasebe ve Finansman Dergisi, Say1 46, 189-198.

Güredin, E., (2007). Denetim ve Güvence Hizmetleri, Arıkan Yayınevi, İstanbul.

Hermanson D. D., Smith J. L., Stephens N. M., (2012). "How Effective are Organizations' Internal Controls? Insights into Spesific Internal Control Elements", Current Issues in Auditing, Vol. 6, No. 1, A31-A50.

Hightower, R., (2009). Internal Controls Policies and Procedures, John Wiley \& Sons, New Jersey.

Kaiser B., Eagan P. D., Shaner H., (2001). "Solutions to Health Care Waste: Life-Cycle Thingking and 'Green' Purchasing", Environmental Health Perspectives, Vol 109, No 3, 205-207.

Mengi, B. T., (2013a). "Satıcı Hileleri”, Muhasebe ve Denetime Bakış Dergisi, Yı1 13, Say1 39, 125-140.

Mengi, B.T., (2013b). Hileli Finansal Raporlama, Beta Yayınevi, İstanbul.

Morrill J. B., Morrill C. K. J., (2012). "Internal Control Assessment and Interference Effects", Behavioral Research in Accounting, Vol. 24, No. 1, 73-90.

Murray J. G., (2009). "Toward A Common Understanding of The Differences Between Purchasing, Procurement and Commissioning in The UK Public Sector", Journal of Purchasing \& Supply Management, Vol 15, 198-202.

Okutmuş, E., Uyar, S., (2014). "Konaklama İşletmelerinde Yiyecek-İçecek Departmanında Yapılan Bir Hilenin Tespiti: Vaka Analizi”, Mali Çözüm Dergisi, Say1 121, 35-54.

Ömürbek, V., Altay, S. Ö., (2011). "Turizm İşletmelerinde İç Kontrol Sisteminin Etkinliğinin İncelenmesi ve Manavgat Bölgesindeki Beş Yıldızlı Otellerde Bir Araştırma", Süleyman Demirel Ü. İ̈BF Dergisi, Cilt 16, Say1 1, 379-402.

Özkul F.U., Özdemir Z.A., (2011). İşletmelerde Hile Riski Yönetimi, Beta Yayınevi, İstanbul.

Özten, S., Karğın, S., (2012). "Bankacılıkta İç Kontrol Faaliyetleri Kapsamında Krediler Kontrolü ve Muhasebeleştirme Süreci”, Afyon Kocatepe Ü. İIBF Dergisi, Cilt 14, Sayı 2, 119-136.

Rae K., Subramaniam N., (2008). "Quality of Internal Control Procedures: Antecedents and Moderating Effect on Organisational Justice and Employee Fraud", Managerial Auditing Journal, Vol. 23, No. 2, 104-124.

Schaeffer M. S., (2002). Essentials of Accounts Payable, Second Edition, John Wiley \& Sons, New York.

Schaeffer M. S., (2004). Accounts Payable, Second Edition, John Wiley \& Sons, New Jersey.

Schaeffer M. S., (2006). Accounts Payable and Sarbanes-Oxley, John Wiley \& Sons, New Jersey.

Schaeffer M. S., (2007a). Travel and Entertainment Best Practices, John Wiley \& Sons, New Jersey. 
Schaeffer M. S., (2007b). Controller and CFO's Guide to Accounts Payable, John Wiley $\&$ Sons, New Jersey.

Schonberger R. J., Gilbert J. P., (1983). "Just-In-Time Purchasing: A Challenge for U.S. Industry”, California Management Review, Vol. 26, No. 1, 54-68.

Schroeder J. H., Shepardson M. L., (2016). Do SOX 404 Control Audits and Management Assessments Improve Overall Internal Control Systme Quality?, The Accounting Review.

Sevim, A., Gül, M., (2012). "Elektronik İşletmelerde Satın Alma İşlemleri ve İç Kontrol İlişkisi”, Afyon Kocatepe Ü. İ̈BF Dergisi, Cilt 14, Sayı 2, 91-118.

Timur, M. N., (2013). “Tedarik Zincirinde Satın Alma ve Örgütsel İlişkiler, Tedarik Zinciri Yönetimi”, Tedarik Zinciri Yönetimi, Anadolu Üniv. Yayınları, Eskişehir, 48-68.

Tuan, K., (2009). "Bağımsız Dış Denetim Sürecinde İç Kontrol Sisteminin İncelenmesi ve Değerlendirilmesi”, Çukurova Ü. İIBF Dergisi, Cilt 13, Sayı 2, 1-15.

Türedi, S., (2012). "İç Kontrol Sistemi ve Toplam Kalite Yönetimi İlişkisi”, Uluslararası Alanya İşletme Fakültesi Dergisi, Cilt 4, Sayı 1, 27-37.

Usul, H., Titiz, İ., Ateş, B. A., (2011). "İç Kontrol Sisteminin Kurumsal yönetimin Oluşumundaki Etkinliği: Marmara Bölgesi Belediye İşletmelerine Yönelik Bir Uygulama", Muhasebe ve Finansman Dergisi, Sayı 49, 48-54.

Uyar, S., (2010). "UFRS Uygulamalarında İç Kontrol Sisteminin Etkisi ve Önemi”, Alanya İşletme Fakültesi Dergisi, Cilt 2, Sayı 2, 37-60.

Uysal, G., (2010). "COSO İç Kontrol Sistemi'nde İnsan Kaynakları Yönetimi: Bütünleşik Çerçeve", Muhasebe ve Finansman Dergisi, Sayı 48, 125-129.

Wells, V.D., (2011). Principles of Fruud Examination, John Wiley \& Sons, New Jersey. 


\title{
Risks and Measures of Purchasing and Payment Activities in Internal Control System
}

\author{
Hakkı FINDIK \\ Kirklareli University \\ Faculty of Economics and Administrative \\ Sciences, Kurklareli, Turkey \\ hakkifindik@klu.edu.tr
}

\section{Extensive Summary}

Purchasing and payment cycle is a process to begin with the needs for goods or services, and to be completed when the payment was made. The excessiveness of documents used in this cycle, large number of working personnel, different departments' participation to the cycle makes it open to fault and fraud. The main aim of controls will be held in purchasing and payment cycle is to provide recognition and reporting for the operations in the cycle to be done in an accurate and complete way. In this study, the risks which are emminent to businesses in the cycle of purchasing and payment, analysis of these risks, possible policies to prevent risks, procedures and impementation and fault-fraud cases are explored.

As it is highlighted in the independent auditor's report; preparation of financial statements, fair presentation, responsibility of providing the information that do not contain significant fault and fraud belong to the business management. According to the results of the research, the auditing activity is insufficient in revealing the fraud. Also because of the increasingly complex and thriving nature of the businesses, specific studies for uncovering frauds are needed. Purchasing and payment cycle is carried out with the participation of internal and external community of shared interest. Internal community of shared interest are shareholders, owners, managers and employees. External community of shared interest are investors, customers, goverment and service providers. In this cycle; the faults and frauds of both internal and external communities of shared interests can be seen. One of the most important steps to obstruct the faults and frauds is to have an effective internal control system. An affective internal control system is only possible with a good design and application. COSO is constituted from eight components of internal control system which are control environment, risk asssesment, control activities, information and communication, monitoring activities, determination of targets, identification of events and responding to risks. Purchasing and payment cycle is explored by dividing five phaces in our work. These phaces are purchase request, purchase order, receiving, recognition and payment.

Purchase request may come from any department of the business. "Purchase Request Order" must be formed by the authurized person or unit and should be sent to purchasing location. Some of the risks that may occur at this phase listed below:

- Unused goods and service demands,

- Double purchases, 
- Inappicable demands to inventory policy,

- Risks caused by communication problems,

- Acquisitions which do not meet the customer requests,

- Non-updated stock levels,

- The difference of quality and quantity between demand or order.

Purchase requests should be evaluated by the purchasing department. This evaluation must be documented via filling a "Purchase Order Form". This form should be sent to the vendor, receiving, accounting and payment departments.

Goods or services must be received by a seperate department of the business. Receiving process should be documented with a "Receival Report".

At the end of receiving process, there will be a debt burden. So this process is the breaking point in the cycle. A vital question in this phase is whether the delivery unit should be aware of the required goods' or services' features (e.g. quantity, quality, price, function) beforehand. The risk in here is the subjected unit's careless performing in receiving although they are aware of the features of the goods or services beforehand. There may be problems such as acceptance of irrelevant goods in the absence of information.

Documents such as "Purchase Request Order", "Purchase Order Form", "Receival Report" are not required for accounting. Required document for accounting is the bill. In the case of not submitting the bill to the the accounting department, there may arise a risk of delays in accounting records. This risk affects directly to the financial reports' preparation processes.

The last phase of the cycle -debt payment- must be performed with the completion of the other phases. So, it is crucial that processes occuring in the cycle should be transferred to the payments unit.

These five phases of the process must be performed effectively with documentation and accounting, the principle of segregation of duties, authorization, done with independent physical control and reconciliation. The principle of segregation of duties requires different people or unit for each task and it is divided to different units. This principle it is intended to prevent fault and fraud of some individual in a closed cycle. Five phases determined within the framework of the cycle must be fulfilled by different units. Authorization is a specific determination of the responsibility for task. This five phase process should be performed by only authorized personnel. The information, document and work-flow must be provided by only responsible persons in the cycle. Taking measures in the flow of information is especially important when they are handled digitally, the access of unauthorized person or unit should be restricted. Control mechanisms should be available during receipt of good or services. The activities of the cycle in question should be made independent from each other. In these phases which are integrated to each other, activities should be documented and a unit should not generate an element of pressure on the other. Aggreement on certain time intervals should be made with both internal and external counterparts. The unit which will provide payment should do the comparison of the "Purchase Order Form", "Receival Report" and "Vendor Bill", and then follow through the payment. 
As a result, the potential risks within the framework of the purchasing and payment cyle must be determined and responses to risks should be prepared. These phases can be determined as purchase requisition, purchase order, receiving, accounting and payment. Personnel who are running at these stages must be authorized. In accordance with the principle of segregation of duties, each phase must be executed by a different emyployee. Operations held in phases must be documented. Protection of entities and data should be provided. Phases should provide independent reconciliation with each other and with non-business parties. In this way, fraud, billing tricks and expense tricks from employees, vendors and employee-employee collaborations, employee-vendor collaborations at the businesses could be avoided. 